\title{
POTENSI 6-AZA-INDAZOLE SEBAGAI TERAPI YANG DAPAT DIPERBAIKI UNTUK PERAWATAN RETINOPATI DIABETIK MELALUI INHIBISI FAKTOR D PENYELESAIAN
}

\author{
Ditta Shabrina $S^{1}$, Ihya Fakrurizal $\mathbf{A}^{\mathbf{1}}$, Afid Brilliana $\mathbf{P}^{\mathbf{1}}$. \\ ${ }^{1}$ Medical Education Study Program, Faculty of Medicine, Muhammadiyah University, Makassar \\ e-mail : dittashabrina@gmail.com
}

\begin{abstract}
Diabetes mellitus is a chronic disease that has a high prevalence in Indonesia. One of diabetes' complications is Diabetic Retinopathy (DR). DR is one of the highest cause of preventable blindness in the world. The treatment for DR up till then uses intravitreal anti-VEGF injection, intravitreal steroid antiinflammation injection. Intravitreal administration can cause some side effects such as increased intraocular pressure and endophthalmitis. Furthermore, patient's convenience is also disturbed, for always having to see a medical personnel frequently. One pathogenesis of $D R$ is the activation of the complement system which causes lysis of endothelial cells and results in ischemic damage to the retina. This ischemic effect will stimulate VEGF secretion that manifests in the phase of Proliferative Diabetic Retinopathy (PDR). Inhibitor of D factor, 6-aza indazole is a small size protein, less than $300 \mathrm{Da}$ which has the potential to inhibit progress of $D R$ by interfering with the activation of alternative pathway (AP) of the complement system. This is supported by the in-vivo test result, where there is a significant inhibition of intraocular AP activation continuously for 8 hours after an oral administration of this agent at a dose of $30 \mathrm{mg} / \mathrm{kg}$. But this study is still in a pre-clinical phase that uses mice as the subject. Therefore, there must be a further study and clinical trial to find out the dosage and safety of this agent to be applied to humans.
\end{abstract}

Keywords : 6-aza indazole, alternative pathway, complement factor D inhibitor, diabetic retinopathy

\begin{abstract}
Abstrak
Diabetes melitus merupakan penyakit kronis yang memiliki prevalensi cukup tinggi di Indonesia. Salah satu komplikasi dari diabetes adalah Retinopati Diabetik (RD). RD merupakan salah satu penyebab kebutaan dapat dicegah yang tertinggi di dunia. Pengobatan untuk RD sejauh ini menggunakan injeksi anti-VEGF intravitreal, dan antiinflamasi steroid intravitreal. Administrasi intravitreal dapat menyebabkan beberapa efek samping seperti peningkatan tekanan intraokular dan endoftalmitis. Selain itu, kenyamanan pasien juga terganggu karena diharuskan mengunjungi tenaga kesehatan secara rutin. Salah satu patogenesis dari RD adalah aktivasi dari sistem komplemen yang menyebabkan lisis dari sel-sel endotel dan mengakibatkan kerusakan iskemia pada retina. Efek iskemia ini akan merangsang sekresi dari VEGF yang bermanifestasi pada fase Diabetik Retinopati Proliferatif (PDR). Penghambat komplemen faktor D, 6-aza-indazole merupakan protein dengan ukuran yang kecil, kurang dari 300 Da yang memiliki potensi untuk menghambat progresi dari RD dengan menginterferensi aktivasi sistem komplemen alternative pathway (AP). Keadaan tersebut dibuktikan melalui uji in-vivo yang menunjukkan penghambatan aktivasi AP signifikan pada intraokular secara terus menerus selama 8 jam pasca pemberian agen peroral dengan dosis $30 \mathrm{mg} / \mathrm{kg}$. Namun, penelitian ini masih berada pada tahap pre-klinik dan baru menggunakan tikus sebagai subjek penelitianya. Sehingga perlu dilakukan penelitian dan uji clinical trial lebih lanjut untuk mengetahui dosis dan keamanan agen ini agar dapat diaplikasikan pada manusia.
\end{abstract}

Kata kunci : 6-aza indazole, alternative pathway, penghambat komplemen faktor D, retinopati diabetik

\section{PENDAHULUAN}

Diabetes melitus adalah penyakit gangguan metabolik yang terjadi karena pankreas yang tidak cukup memproduksi insulin ataupun tubuh yang tidak dapat menggunakan insulin meski insulin sudah diproduksi dengan cukup, sehingga penyakit ini akan menyebabkan terjadinya kondisi hiperglikemia pada pasien. 
Adapun berdasarkan Riset Kesehatan Dasar (Riskesdas) tahun 2013, proporsi penderita diabetes mellitus di Indonesia bernilai $6,9 \% 2$ atau sekitar 12.191 .564 jiwa. Angka ini memberikan gambaran peningkatan senilai hampir dua kali lipat dari riskesdas tahun $2007^{1}$.

Salah satu komplikasi tersering dari diabetes mellitus adalah retinopati diabetik (RD), yang terjadi akibat kerusakan pembuluh darah kecil pada retina ${ }^{1}$. Diperkirakan dari total penderita diabetes mellitus di dunia, satu per tiga penderita menunjukkan tanda tanda RD. Sehingga, meningkatnya penderita diabetes melitus juga meningkatkan risiko kejadian $\mathrm{RD}^{2}$.

Retinopati diabetik adalah salah satu penyebab kebutaan dapat dicegah yang tersering pada pasien dewasa dengan usia 20- 74 tahun di dunia, terutama di negara maju $^{2}$. Selain itu, RD juga menjadi salah satu penyakit mata yang diprioritaskan oleh WHO.3 Berdasarkan pendataan di RSCM, RD menempati peringkat kedua tertinggi komplikasi dari diabetes mellitus dengan nilai $33,4 \%$ dari total penderita diabetes mellitus di RSCM pada tahun $2011^{1}$.

Saat ini tatalaksana RD masih berfokus pada terapi agen anti-VEGF dan antiinflamasi steroid yang diadministrasikan secara intravitreal, serta laser fotokoagulasi. Akan tetapi, tidak semua pasien merespon terhadap terapi yang diberikan. Selain itu, penggunaan anti-VEGF intravitreal masih terbatas karena membutuhkan frekuensi injeksi yang tinggi, mahal, dan juga buruknya compliance pasien. Injeksi intravitreal juga dapat menyebabkan berbagai efek samping seperti endoftalmitis dan peningkatan tekanan intravitreal. ${ }^{4}$

Melihat tingginya angka RD dan belum efektifnya terapi yang tersedia, maka dibutuhkan agen yang mampu memberikan compliance yang lebih baik, serta efek samping yang lebih rendah. Untuk itu, penulis ingin mencari tahu kemungkinan 6-azaindazole sebagai terapi retinopati diabetik yang lebih efektif.

\section{METODE}

Penulis melakukan pencarian literatur pada sejumlah database seperti Pubmed, Sciencedirect, dan Scopus. Pencarian dilakukan dengan memasukkan kata kunci antara lain, "Factor D", “inhibitor", "alternative pathway" dan "diabetic retinopathy" sehingga diperoleh sejumlah literatur yang kemudian disintesis menjadi sebuah telaah pustaka. Penulis juga menggunakan data dari Kementerian Kesehatan dan WHO untuk menunjang pembuatan telaah pustaka ini. Kriteria inklusi yaitu jurnal berbahasa Inggris dan sesuai dengan kata kunci. Kriteria eksklusi pada penelitian ini adalah publikasi yang lebih dari 10 tahun.

\section{TINJAUAN PUSTAKA}

\section{Retinopati diabetik}

Retinopati diabetik adalah komplikasi mikrovaskular akibat diabetes dan masih menjadi penyebab utama kebutaan pada masyarakat usia pekerja yang seharusnya dapat dicegah. ${ }^{5}$

Definisi, diagnosis, dan tatalaksana RD didasarkan pada seberapa luas penyakit vaskular di retina dapat terdeteksi melalui pemeriksaan oftalmoskop. Tiga bentuk RD antara lain: (1) edema makular, meliputi kebocoran vaskular fokal atau difus pada makula; (2) akumulasi perubahan mikrovaskular progresif yang meliputi mikroaneurisma, perdarahan intraretinal, dan malformasi vaskular (dikenal sebagai retinopati diabetik nonproliferatif) yang dapat menyebabkan pertumbuhan vaskular abnormal pada diskus optik atau retina (dikenal sebagai retinopati diabetik proliferatif); dan (3) nonperfusi kapiler retina akibat adanya penyumbatan vaskular yang terdeteksi melalui angiografi retina. Penyumbatan diduga merupakan komplikasi diabetes yang menyebabkan kebutaan dan belum ada tatalaksananya ${ }^{6}$. 


\section{Patogenesis retinopati diabetik}

a. Patogenesis terkait inflamasi

RD merupakan keadaan progresif dengan mikroaneurisma dan perdarahan kecil yang dapat disertai dengan iskemia retina, gangguan permeabilitas, dan neovaskularisasi. Penyumbatan pada kapiler akan menyebabkan gangguan perfusi di area retina sehingga terjadi iskemia. Beberapa jam setelah iskemia, terjadi aktivasi dan inflamasi sel glial retina. Sel glial teraktivasi akan melepaskan substansi sitotoksik berbeda yang dapat menghancurkan sawar darah, mengundang infiltrasi leukosit, dan menyebabkan disfungsi pembuluh darah. Tidak hanya faktor inflamasi, patogenesis $\mathrm{RD}$ ternyata juga melibatkan adanya 3 neovaskularisasi. Vascular endothelial growth factor (VEGF) diketahui berkontribusi dalam angiogenesis dan kehadirannya mempengaruhi permeabilitas pembuluh darah. Beberapa tahun terakhir, selain VEGF juga terdapat beberapa faktor lain yang berperan dalam progresi $\mathrm{RD}$, antara lain, sitokin proinflamasi dan kemokin seperti IL-1 $\beta$, IL-6, dan interferon- ${ }^{7}$.

\section{b. Patogenesis terkait komplemen}

Beberapa tahun terakhir, sistem komplemen banyak menarik minat penelitian di bidang oftalmologi. Sistem komplemen tergolong imunitas bawaan dan kerjanya terbagi ke dalam 3 jaras, yaitu klasik, mannose-binding lectin, dan alternatif $^{8}$ Meskipun diabetes tidak termasuk penyakit yang dimediasi komplemen, namun sejumlah data menunjukkan keterkaitan antara progresi RD dan disregulasi komplemen. Ditemukan adanya peningkatan ekspresi beberapa faktor komplemen pada vitreous pasien RD yang terdiri dari 30 lebih protein kecil dan fragmen protein. Beberapa regulator yang meningkat pada pasien retinopati diabetik proliferatif (PDR) adalah C3 dan komplemen faktor B (FB). Pembelahan C5 bersama C3 menjadi satu dari dua tahapan kritis dalam aktivasi sistem komplemen. Regulator yang turut memainkan peran kunci aktivasi sistem komplemen alternative pathway (AP) adalah komplemen faktor $\mathrm{D}$ (FD) ${ }^{10}$ Menurut Manoharan, et al, FD diketahui meningkat signifikan pada pasien PDR dibandingkan dengan kontrol $(p=0.001)$. Kondisi tersebut menunjukkan bahwa jaras komplemen AP mengalami peningkatan regulasi pada pasien PDR. FD akan memotong FB yang memproduksi $C 3$ convertase dan berakibat pada teraktivasinya jaras komplemen alternatif. ${ }^{8}$ Sistem komplemen yang teraktivasi penuh kemudian menghasilkan formasi membrane attack complex (MAC) yang dapat membunuh patogen. Namun, formasi MAC pada beberapa kondisi justru menyebabkan neurodegenerasi dan perubahan permeabilitas vaskular sel host. Tidak hanya itu, produk pembelahan komplemen juga menghasilkan efek kemotaksik pada neutrofil, sel mast, dan limfosit yang berpotensi mengeksaserbasi respon inflamasi. ${ }^{9}$

Mekanisme yang mendasari perkembangan RD adalah paparan kronik hiperglikemia dan sejumlah faktor risiko kausatif seperti hipertensi. Keadaan tersebut memicu kaskade biokimia dan perubahan fisiologis yang menyebabkan kerusakan mikrovaskular dan disfungsi retina. Misalnya saja hiperglikemia yang akan meningkatkan stress oksidatif. ${ }^{5}$ 


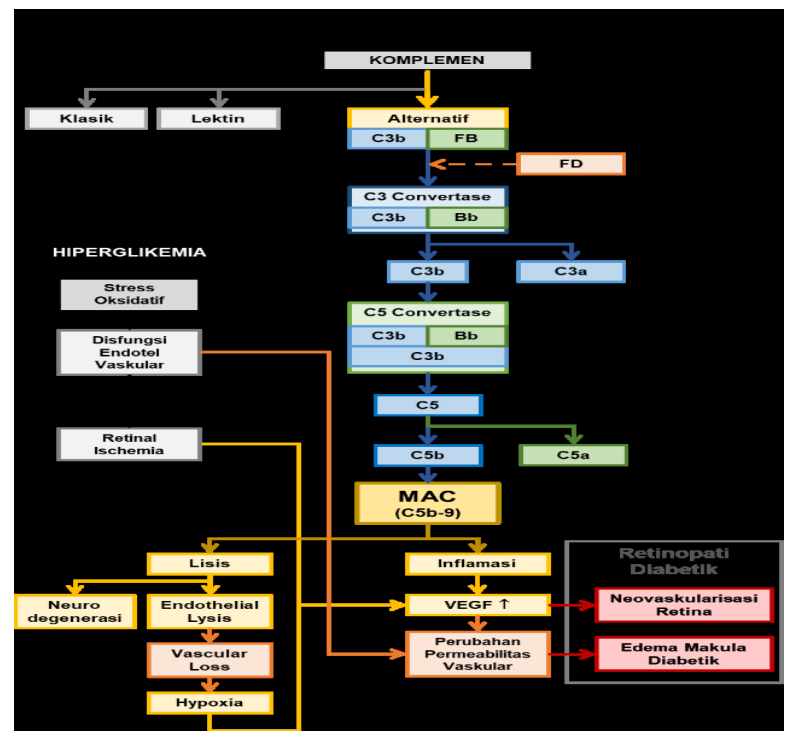

Gambar 1. Patogenesis retinopati diabetik melalui sistem komplemen alternative pathway. ${ }^{5,-11}$

Stress oksidatif terjadi akibat berlebihnya produksi spesies oksigen reaktif (SOR) dan/atau berkurangnya peran antioksidan, yang dapat menyebabkan kerusakan seluler. Peningkatan stress oksidatif diduga memainkan peran penting dalam memicu berbagai komplikasi diabetes, termasuk RD. Menurut Thurman et al, stress oksidatif diperkirakan juga terlibat dalam aktivasi sistem AP dan diasosiasikan dengan kerusakan sel epitel pigmen retinal terkait komplemen. Kerusakan sel epitel pigmen retinal invitro ditentukan menggunakan pengukuran resistensi transepitelial. ${ }^{8,11}$

\section{Terapi retinopati diabetik saat ini}

\section{a. Obat anti-VEGF}

Hingga saat ini, anti-VEGF intravitreal adalah terapi lini pertama yang digunakan 4 untuk RD. Obat jenis ini menargetkan protein subfamili VEGF, yang diekspresikan berlebih pada pasien RD sehingga akan menghambat lesi prekursor $\mathrm{RD}$ dengan mereduksi permeabilitas vaskular, serta mereduksi neovaskularisasi retina dan koroid. Akan tetapi, terapi ini memiliki banyak kekurangan, utamanya adalah kurangnya compliance pasien karena pengobatan yang mahal dan dilakukan dengan injeksi intravitreal.
Selain itu, pengobatan bersifat sering karena agen anti- VEGF memiliki waktu paruh yang singkat, sehingga diperlukan pengulangan injeksi intravitreal setiap satu atau dua bulan. Selain compliance yang rendah, seringnya pengulangan injeksi intravitreal pada pasien juga dapat mengakibatkan terjadinya endoftalmitis., ${ }^{42}$

\section{b. Obat anti inflamasi steroid}

Kortikosteroid intravitreal digunakan untuk terapi terutama bagi pasien RD yang tidak merespon terhadap terapi anti-VEGF. Kortikosteroid memiliki efek antiinflamasi serta anti-angionegik yang tinggi dengan memodulasi berbagai mediator proinflamasi seperti TNF- $\alpha$ dan IL-1 $\beta$, selain itu terapi kortikosteroid juga memiliki aktivitas pada VEGF. Pemberian kortikosteroid secara intravitreal dilakukan untuk mencegah obat harus melalui bloodretinal-barrier. Akan tetapi, efek terapi kortikosteroid bersifat singkat, sehingga juga harus dilakukan pengulangan dari injeksi. Banyaknya pengulangan dari injeksi intravitreal kortikosteroid ini dapat menyebabkan katarak dan peningkatan tekanan intraokuler.4,12,13 Adapun kortikosteroid implan merupakan suatu implan yang dapat terbiodegradasi, lepas lambat, dan terdiri atas kompleks obatkopolimer yang akan perlahan melepaskan 
obat dalam beberapa bulan. Akan tetapi penggunaannya kortikosteroid ini dapat menyebabkan peningkatan tekanan intraokuler. ${ }^{13}$

\section{c. Terapi laser}

Terapi laser (laser photocoagulation) masih merupakan terapi dukungan utama untuk RD. Terapi laser focal/grid macular dapat meringankan edema pada makula dan mengurangi risiko kehilangan penglihatan sedang sebesar 50\%, sedangkan PRP atau panretinal photocoagulation digunakan untuk tatalaksana PDR dan mengurangi risiko kehilangan penglihatan berat. Akan tetapi, penggunaan laser untuk terapi pada $\mathrm{RD}$ juga memiliki sifat destruktif sehingga dapat menyebabkan berbagai efek samping okular dan apabila kehilangan penglihatan sudah terjadi, pengembalian kemampuan melihat jarang dapat terjadi meski sudah diberikan terapi laser yang adekuat. ${ }^{4,5}$

\section{HASIL DAN PEMBAHASAN}

\section{Hasil}

\section{Kimia}

Metode dalam penemuan penghambat FD ini adalah melalui seleksi in-silico yang diawali dengan screening molekul dengan sifat sama dengan penghambat FD yang sudah dikarakterisasi dan masuk ke dalam protein databank (1DIC) serta memiliki berat molekul di bawah 350 Da. ${ }^{14,15}$ Setelah mendapat karakteristik substansi yang sama dengan 1DIC akan dilakukan docking untuk mengetahui afinitas ikatan terhadap FD milik manusia. Seleksi dari masing-masing calon agen dilakukan dengan cara pendekatan struktural 3D dan afinitas ikatan terhadap FD manusia. Dari hasil telaah bioinformatik tersebut didapatkan suatu molekul bernama 6- aza-indazol yang memiliki afinitas kuat dan bekerja spesifik terhadap FD. ${ }^{14}$

\section{Farmakodinamik}

Molekul ini dengan ukuran kurang dari 300 Da akan berikatan dengan FD, sehingga bersifat antagonis terhadap ligand aslinya yaitu C3BFB untuk diubah menjadi $\mathrm{C} 3 \mathrm{bBb} \quad$ (C3 convertase). Dikarenakan inhibisi ini berada pada hulu dari jalur AP maka FD ini menjadi faktor limitasi dari laju pembentukan MAC pada jalur AP. Inhibisi pada FD diyakini dapat menekan pembentukan MAC melalui jalur AP. ${ }^{14}$

Pada penelitian yang sama dilakukan untuk mengidentifikasi potensi dari agen ini sebagai agen selektif adalah melihat kemampuan ikatan terhadap protein yang terlibat dalam jalur inflamasi yang sama. Sudah dilakukan uji menggunakan spektroskopi untuk melihat apakah 6-azaindazole ini berikatan secara spesifik pada FD atau berikatan juga pada FB yang merupakan salah satu komponen dari AP. Hasil ditampilkan pada gambar 2 menunjukkan terjadinya ikatan yang spesifik antara molekul 6-aza-indazole terhadap FD. ${ }^{14}$ 




Gambar 2. Kemampuan ikatan 6-aza-indazole dibandingkan antara FD dan FB. ${ }^{1}$

a

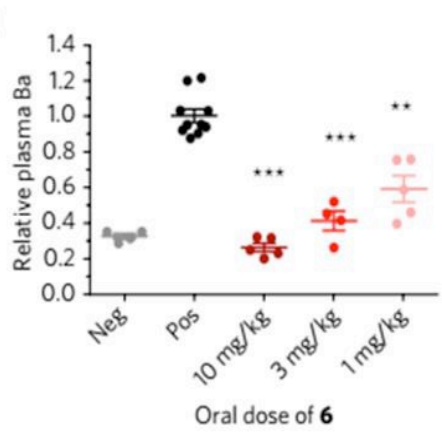

b

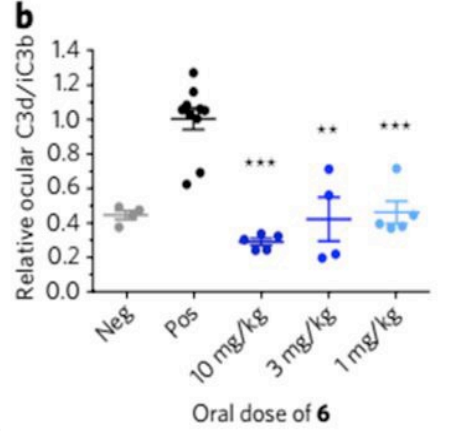



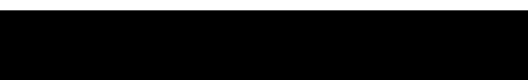

Gambar 3. (a) menunjukkan kadar Ba pada plasma pasca pemberian LPS (pos), dan pemberian dosis oral 6aza-indazole pada konsentrasi tertentu $(10,3$, dan $1 \mathrm{mg} / \mathrm{kg})$ (b) perlakuan sama seperti grafik (a) tetapi pengukuran pada kadar C3d/iC3b okular (c) menunjukkan lama waktu inhibisi pasca pemberian $30 \mathrm{mg} / \mathrm{kg}$ secara oral. ${ }^{14}$

\section{Farmokokinetik}

Setelah mengetahui bahwa substansi tersebut bekerja spesifik secara farmakodinamik, akan dibahas aplikasinya secara in-vivo untuk mengetahui onset kerja obatnya dan administrasinya. Uji ini dilakukan in-vivo pada mencit (strain C57B1/6) yang sudah diekspresikan molekul FD milik manusia (human-FD knock-in (KI) mice). Sehingga FD milik mencit memiliki karakteristik yang sama dengan yang diekspresikan pada manusia. ${ }^{14,15}$

Berdasarkan tinjauan pustaka yang sudah dipaparkan diatas, pada pasien RD terjadi peningkatan jumlah komponen AP yang meningkat signifikan. Sehingga pada mencit uji, dilakukan stimulasi memakai LPS yang merupakan agen yang dapat meningkatkan komponen AP seperti C3b dan Ba (derivat dari faktor B). Pada gambar 3 menunjukkan kemampuan inhibisi dari 6-aza-indazole pasca administrasi secara oral pada $\mathrm{Ba}$ dan $\mathrm{C} 3 \mathrm{D}$ yang merepresentasikan aktifnya jalur AP. ${ }^{14}$.Sesuai pada gambar 3 (a) dan (b) menunjukkan terjadinya inhibisi pada komponen AP dari plasma dan intraokular saat pemberian obat secara peroral jika dibandingkan kontrol positif dengan pemberian LPS yang berfungsi untuk menginisiasi pembentukan MAC melalui 
jalur AP. Pada plasma untuk ketiga dosis terdapat perbedaan signifikan dibandingkan kontrol positif. Pada jalur aktivasi komplemen AP intraokular juga menunjukkan inhibisi secara signifikan dibandingkan kontrol positif. ${ }^{14}$

Pada gambar 3 (c) menunjukkan terdapat kondisi inhibisi yang dipertahankan selama 8 jam pasca pemberian peroral 6aza-indazole dengan dosis $30 \mathrm{mg} / \mathrm{kg}$. Pada gambar tersebut juga mengindikasikan inhibisi pada komplemen pada jalur AP berada di bawah garis kontrol yaitu ditunjukkan dengan garis bertanda PBS. ${ }^{14}$

\section{Pembahasan}

Retinopati diabetik merupakan penyakit akibat komplikasi diabetes yang menyebabkan hipoksia pada lapisan retina. Hipoksia ini diketahui juga memberikan dampak pada peningkatan jumlah aktivasi komplemen AP sehingga menimbulkan kerusakan pada sel-sel neuron sekitar dan memberikan dampak pada lapang penglihatan pasien. Terapi yang saat ini digunakan untuk RD adalah anti-VEGF dan antiinflamasi steroid intravitreal. Terapi-terapi tersebut tidak hanya memiliki banyak efek samping, tetapi juga memberikan efek rendahnya compliance pasien untuk rutin datang berobat ke dokter. ${ }^{14,15}$

Penghambat FD selektif, 6-aza-indazole diadministrasikan peroral dengan dosis 30 $\mathrm{mg} / \mathrm{Kg}$ pada mencit menunjukkan inhibisi sistem komplemen AP terus menerus selama 8 jam pasca administrasi. Selain itu meskipun rute administrasi secara peroral, terdapat inhibisi komplemen pada okular yang signifikan dibandingkan kontrol pada uji in-vivo mencit, hal ini menunjukkan obat ini memiliki efikasi yang cukup baik pada administrasi oral. Dengan waktu kerja obat bertahan hingga 8 jam, obat ini dapat diberikan tiga kali sehari secara peroral. Hal ini dapat meningkatkan compliance pasien untuk konsisten minum obat dibandingkan dengan obat yang diadministrasikan secara intravitreal. ${ }^{14}$

\section{KESIMPULAN DAN SARAN}

Retinopati diabetik merupakan penyakit akibat komplikasi mikrovaskular dari diabetes melitus. Pengobatan saat ini masih menggunakan anti-VEGF dan antiinflamasi steroid yang diinjeksikan pada mata dapat memberikan beberapa efek samping seperti endoftalmitis dan peningkatan tekanan intraokular. 6-azaindazol merupakan agen yang memiliki cara kerja menghambat pembentukan sistem komplemen dan dapat diadministrasikan secara oral dengan tetap mempertahankan efikasi pada intraokular. Agen ini dirasa sangat baik jika bisa diberikan pada pasien dengan $\mathrm{RD}$ dikarenakan dengan administrasi secara oral maka dapat meningkatkan kepatuhan pasien serta mengurangi efek samping dari pemberian secara intravitreal. Penulis menyarankan agar dilakukan penelitian lebih lanjut untuk mengetahui dosis secara tepat pada manusia, dikarenakan peneltiian yang sejauh ini dilakukan hanya sebatas uji in-vivo pada mencit dan monyet.

\section{REFERENSI}

1. Kementerian Kesehatan RI Pusat Data dan Informasi. Situasi dan Analisis Diabetes. Jakarta: Kemenkes RI; 2014. p. $1-8$

2. Lee R, Wong TY, Sabanayagam C. Epidemiology of diabetic retinopathy, diabetic macular edema and related vision loss. Eye and Vision [Internet]. 2015 Sep 30;2(1). Available from: http://dx.doi.org/10.1186/s40662-0150026-2

3. World Health Organization, Blindness and Vision Impairment Prevention. Jeneva: WHO; 2019. Available from : https://www.who.int/blindness/causes/ prio rity/en/index $5 . h t m l$

4. Wang W, Lo A. Diabetic Retinopathy: Pathophysiology and Treatments. Int J Mol Sci [Internet]. 2018 Jun 20;19(6):1816. Available from: 
http://dx.doi.org/10.3390/ijms1906181 6

5. Cheung N, Mitchell P, Wong TY. Diabetic retinopathy. Lancet [Internet]. 2010;376(9735):124-36. Available from: http://www.sciencedirect.com/science/ arti cle/pii/S0140673609621243

6. Altomare F, Kherani A, Lovshin J. Retinopathy. Can J Diabetes [Internet]. 2018;42:S210-6. Available from:

http://www.sciencedirect.com/science/ arti cle/pii/S1499267117308377

7. Tsai T, Kuehn S, Tsiampalis $\mathrm{N}, \mathrm{Vu}$ M-K, Kakkassery V, Stute G, et al. Anti-inflammatory cytokine and angiogenic factors levels in vitreous samples of diabetic retinopathy patients. PLoS One [Internet]. 2018;13(3):1-13. Available from: https://doi.org/10.1371/journal.pone.0 194603

8. Manoharan N, Patnaik JL, Olson JL. Increased complement levels in human vitreous aspirates of proliferative diabetic retinopathy and retinal detachment eyes. Retina [Internet]. 2018 Aug;1. Available from:

http://dx.doi.org/10.1097/IAE.000000 0000002288

9. Rübsam A, Parikh S, Fort PE. Role of inflammation in diabetic retinopathy. Int J Mol Sci [Internet]. 2018;19(4). Available from: http://www.mdpi.com/14220067/19/4/942

10. Stanton CM, Yates JRW, den Hollander AI, Seddon JM, Swaroop A, Stambolian D, et al. Complement factor $\mathrm{d}$ in age-related macular degeneration. Invest Ophthalmol Vis Sci [Internet]. 2011 Nov 11;52(12):8828-34. Available from: https://doi.org/10.1167/iovs.11-7933

11. Thurman JM, Renner B, Kunchithapautham K, Ferreira VP, Pangburn MK, Ablonczy $\mathrm{Z}$, et al. Oxidative stress renders retinal pigment epithelial cells susceptible to complement-mediated injury. J Biol Chem [Internet].2009 Jun 19;284(25):16939-47. Available from:

http://www.jbc.org/content/284/25/16 939. abstract

12. Lu L, Jiang $\mathrm{Y}$, Jaganathan $\mathrm{R}$, Hao $\mathrm{Y}$. Current Advances in Pharmacotherapy and Technology for Diabetic Retinopathy: A Systematic Review. Journal of Ophthalmology [Internet]. 2018;2018:1- 13. Available from: http://dx.doi.org/10.1155/2018/16941 87

13. Miller K, Fortun JA. Diabetic Macular Edema: Current Understanding, Pharmacologic Treatment Options, and Developing Therapies. AsiaPacific Journal of Ophthalmology [Internet]. 2018;7(1). Available from: http://dx.doi.org/10.22608/apo.201752 9

14. Maibaum J, Liao S-M, Vulpetti A, Ostermann N, Randl S, Rüdisser S, et al. Small-molecule factor D inhibitors targeting the alternative complement pathway. Nature Chemical Biology [Internet]. 2016 Oct 24;12(12):110510. Available from: http://dx.doi.org/10.1038/nCHeMBIO. 2208

15. Loyet KM, Good J, Davancaze T, Sturgeon L, Wang X, Yang J, et al. Complement Inhibition in Cynomolgus Monkeys by Anti-Factor D Antigen- Binding Fragment for the Treatment of an Advanced Form of Dry Age-Related Macular Degeneration. J Pharmacol Exp Ther [Internet]. 2014 Sep 17;351(3):527$37 . \quad$ Available from: http://dx.doi.org/10.1124/jpet.114.215 921 